\title{
Knowledge and Decision Making - Do We Want What We Need?
}

\author{
Bogdan Lipicnik \\ University of Ljubljana, Ljubljana, Slovenia
}

\author{
bogdan.tipicnik@uni-ti.si
}

\begin{abstract}
Knowledge is a category that includes many past decisions. They could be good for the past but it is a question if they can work in the future. We can talk about programmed and non-programmed decisions. When a predetermined situation triggers a predetermined response we can talk about a programmed decision. If one wants to make a non-programmed decision he/she must search for information, identify the problem, evaluate possible alternatives, and act. If the process is more complicated, programmed decision will be more effective. Our research has revealed that future managers in Slovenia possess knowledge that involves more programmed that non-programmed decisions. This may indicate that they will have a lot of difficulties with decision making in complicated organisational systems. However, they cannot learn how to take decisions (even if they want to) because they do not know what they actually need. If they are successful at non-programmed decisions they want more knowledge from the same area; in fact they would need more knowledge about programmed decisions - and vice versa.
\end{abstract}

Keywords: knowledge, learning, decision making, management, education, team, problems.

\section{Knowledge and Mode of Decision Making}

Knowledge may be considered as an overview of past decisions that proved to be effective. Thus, knowledge is past in its very nature. People are being educated in order to make today's decisions effective in the future. However, today's decisions cannot comprise all circumstances that may emerge in the future at the time of their implementation. Therefore it is not difficult to refer to the proverb, namely that "everybody can be the general after the battle". Historians, however, know all the circumstances while the defeated general could not envisage.

A lot of decisions are taken in every organisation. They are also very diverse. Despite, all types of decisions may be classified in two categories that differ essentially: programmed and non-programmed decisions.

\section{Programmed Decision Making}

Referring to computer terminology every decision is the one that defines a specific task for the computer. Thus, system of stocks is a programmed decision. Minimum stocks are defined in advance. When they reach the bottom line the computer "decides" and writes an order form. So, when a predetermined situation triggers a predetermined response we can talk about programmed decisions. There are numerous ex-

Material published as part of these proceedings, either on-line or in print, is copyrighted by Informing Science. Permission to make digital or paper copy of part or all of these works for personal or classroom use is granted without fee provided that the copies are not made or distributed for profit or commercial advantage AND that copies 1) bear this notice in full and 2) give the full citation on the first page. It is permissible to abstract these works so long as credit is given. To copy in all other cases or to republish or to post on a server or to redistribute to lists requires specific permission from the publisher at publister@intormingscience.org amples from practice. When people go home from their jobs they only get aware of the situation when they come to the front doors of their homes. In a certain moment they can remember nothing but events happening while they were leaving their jobs. What was happening in-between, which streets they were driving or walking along, which traffic lights were green and which were red - they 
cannot remember anymore. How could they possibly come home? In a programmed way. The whole way was certainly full of decisions but all reactions were programmed. People are learned to stop in front of red traffic light, to turn left or right when needed, to turn the steering wheel, to press the brake or the clutch, to change gears - and we can do that unconsciously, in a programmed way. Woe to us, if our programming fails! It would mean that an individual should think about how to drive home from work every single time. Those who act exactly like this (for different reasons) are potentially responsible for traffic accidents.

\section{Non-programmed Decision Making}

Non-programmed decisions are taken when people do not have enough information or when they find themselves in previously unknown situations. Anyway, people must search for appropriate information, identify the problem, evaluate possible alternatives and act adequately. We will take as an example the same situation as for programmed decisions. You are driving home and somebody suddenly drives in the middle of the crossroads while there is a red light on. Since this is not in accordance with the rules there is no "in-programmed" decisions ad you should search for appropriate information about his/her speed, about his/her direction, whether this influences your driving etc. You have to make a decision among alternatives: whether to speed up, to stop, or to turn left or right etc. However, you can act only after the process of collecting information and evaluating decisions is completed. In this case no piece of information is known in advance. Non-programmed decisions require creativity and readiness to take risk. If a person is not creative he/she cannot define the course of the action and neither can he/she understand that the situation is unusual and thus a non-programmed decision is required. Although a programmed reaction may whitewash you at the court in this case, the problem of collision has not been solved. Many entrepreneurs fail by reacting in a programmed way without knowing that different decisions are required in different situations - the decisions that have not been programmed yet. When we drive along unknown roads through unfamiliar towns we have to make non-programmed decisions that require creativity (to create and evaluate alternatives) and risk (which alternative to choose).

\section{Decision Making and Education}

If a simple explanation about programmed and non-programmed decisions is applied to enterprises we can realise that the more complicated the system grows the more effective programmed decisions become. Thus, too much time would be spent to take non-programmed decisions in enterprises where a lot of people are employed and where a lot of synchronised activities must be performed. We could probably witness a real mess! Non-programmed decisions, on the other hand, are more popular in organisations where every employee works in his/her own professional area without special links with other colleagues.

Mode of decision making is also interwoven in individual's behaviour pattern. Regardless of how this pattern is created, we can talk about a relatively stable mode of decision making. Thus, it is possible to notice one's mode of decision making from learning his/her behaviour pattern. Besides, it is possible to notice his/her aspiration for certain type and certain content of education.

\section{Behaviour Roles}

If we borrow Adize's definition and classification of behaviour pattern, we could realise that a person whose behaviour pattern includes behaviour role indicated by $\mathrm{P}$ will subordinate his/her decisions to short-term effectiveness. Progress is not important for this person. For him/her it is important that as much as possible is being done in a certain moment - although it is about performing senseless of even stupid activities. For this person all decisions are in-programmed. He/she knows exactly how something can be done in the fastest way. Effectiveness of his/her decisions is measured by quantity of completed activities. 
A person whose behaviour pattern includes behaviour role indicated by A will subordinate his/her decisions to tendency towards short-term efficiency. It is important for him/her that every detail is envisaged and possibly noted down in different rule books. His/her decisions are subordinated exclusively to programmed decisions. He/she is very unhappy and even confused if decisions are not programmed and noted down in advance. He/she considers the need for non-programmed decisions as disorderly system which he/she constantly criticises.

A person whose behaviour pattern includes behaviour role indicated by $\mathrm{E}$ aims at long-term effectiveness. Or he/she at least believes firmly that he/she must perform differently and that every decision must be based on pre-established information. His/her continuous non-programmed decisions produced by a number of his/her ideas make him/her believe in better future, in effectiveness that will be obvious only some time afterwards.

Future success is also expected by a person whose behaviour pattern includes behaviour role indicated by I. His/her decisions are subordinated to long-term efficiency which is viewed as appropriate human resource management by such person. He/she also tends to take non-programmed decisions. In this case people cannot control the effects of his/her decisions since the results may only be seen some time afterwards.

\section{Behaviour Roles and Education}

Behaviour roles within an individual's behaviour pattern strongly influence attitude towards education. A person with behaviour role indicated by $\mathrm{P}$ may thus believe that work itself is the best teacher. It means that one should be educated (trained) in a practical way by using the method of attempt and failure, and learns it on one's own cost. Every type of education outside his/her working premises is a mere waste of time for such a person. Work - an you can learn everything you need!

A person whose behaviour pattern includes behaviour role indicated by A believes that one should be given the rules laid down by others and he/she should follow them strictly. Learning new rules and regulations seems to him/her the only type of education that makes sense. Attending courses and other types of education should be conditioned by regulations. Typical question that may be asked by this type of person: Is he/she entitled to this type of education/training; is it in accordance with the rule-book?

Behaviour role indicated by E, which may be found in an individual's behaviour pattern, requires that an individual tries to transfer his/her, ideas to other people himself/herself. This tendency is so impetuous that he/she conceals ideas until he/she manages to create problems in people; then he/she triumphs by revealing pre-prepared solutions. He/she attends only those types of education/training where he/she can reveal his/her ideas. He/she is not interested in other people's ideas or he/she considers them invaluable. $\mathrm{He} / \mathrm{she}$ is not interested in education/training which he/she considers as a mere transfer of programmed decisions.

People whose behaviour pattern includes behaviour role indicated by I are above all interested in topics where people are educated/trained in how to work with other people. They consider every activity aimed at people as an art of communication. Regardless of what problems people might have such persons believe that knowledge of communication is a proper solution. This tendency is completely understandable for them because they can approach people only by help of communication.

This is how people are and nothing is wrong with that. Relationship between behaviour roles included in behaviour patterns of every individual can help us understand the issue why every individual acts in the process of education and/or training in a different way. 


\section{Education/Training and Organisations' Behaviour Patterns}

It is essential for every organisation that it is oriented towards future as well as towards present and that it aims to effectiveness and productiveness. Therefore those organisations that employ people with all roles in behaviour patterns (although such perfection cannot be found in one person) seem to be the most effective. If people with same behaviour roles in their behaviour patterns were employed in an organisation, this organisation could not be effective. Therefore organisations have to find out which behaviour roles they lack in their behaviour patterns first and then develop education and training programmes that will help them fill the gap in their behaviour structure. Besides, education and training programme providers should be aware of which behaviour roles should be reinforced and how this could be achieved.

However, we may face the first serious problem already at the starting point: Those people who belong to certain behaviour roles in their behaviour patterns usually believe that they need only those knowledge and skills that arise from their behaviour pattern instead of considering organisational needs. Therefore they will develop and order educational and training programmes that are based on their behaviour patterns without considering organisational needs because these people are simply not aware of other needs than their own. Serious educational and training institutions, that offer such programmes, should offer what organisations need. But it is definitely much easier to sell what organisations offer.

The second problem appears when programmes are being implemented. People with specific behaviour roles in their behaviour patterns should reinforce behaviour roles that have not been detected. So educational and training institutions should do something against participants' will because they themselves do not know what they need. Unfortunately, such attempts have mostly been evaluated as an educational or training failure. However, we know the ways to evoke a behaviour role that has not been implied in one's behaviour pattern.

If we wanted to develop $\mathrm{P}$ and A role people should be given work that requires application of behaviour role $\mathrm{P}$ and $\mathrm{A}$. Considering the fact that they aim mostly at short-term effectiveness $(\mathrm{P})$ and short-term efficiency (A), it is necessary for the development of behaviour role $\mathrm{P}$ to assign a person such tasks that offer an instant possibility of establishing whether they have been completed or not. Or: Success may be instantly ascribed to a person who has completed the tasks. Behaviour role A requires a system order, details, programmed decisions, envisaged events and enjoyment in routine. Therefore behaviour role A can be developed when a specific task is assigned to a learner and when he/she has to programme decisions himself/herself. Envisaging events is thus required by a task. There are more than enough tasks like this in every organisation.

While organisations are relatively successful at development of $\mathrm{P}$ and $\mathrm{A}$ behaviour roles, they are less skilful in development of behaviour roles E and I in employees' behaviour patterns. In many organisations future directions, future effectiveness and efficiency are left to directors or top managers. If they do not have such people they are searching for them outside their organisation. This may even impede eventual natural development of behaviour roles E and I in employees' behaviour patterns. On the contrary, at schools and at universities these two behaviour roles are being strongly developed by allowing pupils and students to solve different tasks in their own way. Creativity as a result of a range of ideas may be released in this case. Since tasks are often performed in groups it is necessary to use various communication channels. Outwardly, the type of education and training that helps develop behaviour roles I and E may be perceived as a problem solving activity based on one's own experiences; however, it is less appropriate for those who need this type of education and training ( $\mathrm{P}$ and $\mathrm{A})$.

Finally, regular development of all behaviour roles in employees' behaviour patterns is one of the purposes of a learning organisation. 


\section{Behaviour Patterns of Future Managers}

We were interested in behaviour patterns of students at The Business School, Faculty of Economics in Ljubljana. An extensive research, which included about 800 students, indicated that the major part of this cohort is oriented towards future concerning efficiency as well as effectiveness. In other words, behaviour roles $\mathrm{E}$ and I were most frequently found in their behaviour patterns while behaviour roles $\mathrm{P}$ and $\mathrm{A}$ were often missing.

If these findings are connected to the previously described principles, they may indicate that students are mainly inclined to non-programmed decision making, i.e. decision making where the choice among alternatives should be made, where no information is known in advance and where creativity and risk are required. This may be a result of methods of education where individual, group or team problem-solving is common practice. At the same time, their behaviour patterns possibly influence university professors to use teaching methods that allow students to test the development of ideas individually. Creativity is a category that is extremely appreciated by students.

Frequent absence of behaviour roles $\mathrm{P}$ and $\mathrm{A}$ could mean that making programmed decisions may be a very serious hindrance for these students. Short-term efficiency and effectiveness are also less interesting for them. Difficulties of this kind may be noticed mainly by those types of tasks where a specific report or another concrete product should be completed according to pre-determined programmed procedures. Absence of such types of tasks is very common.

\section{Conclusions}

If we presume that behaviour patterns of present students will not be significantly altered in practice or that only people of such behaviour patterns could occupy top management positions (it is only a theoretical presumption) and thus take decisions about how and in relation to what their employees can be educated and trained they would probably act in accordance with their behaviour patterns. They would try to transfer their own ideas to others themselves. However, they would participate in education and/or training only if they could reveal their own ideas to other people. They would not be interested in other people's ideas. They would not impede their colleagues' education and/or training but they would also leave development of education and training programmes to other people. There would be at least two indispensable themes in each programme: communication and human resource management.

From the aspect of prevailing opinion in Slovenia there is nothing wrong with such behaviour of future managers or it is even perceived as desired behaviour. However, it is critical that behaviour roles $\mathrm{P}$ and $\mathrm{A}$, which indicate short-term effectiveness and efficiency, are thus neglected. There is not a promising situation for any staff if behaviour roles $\mathrm{P}$ and $\mathrm{A}$ in staff's behaviour patterns are missing. Therefore an essential question should be asked: How to convince managers of the described behaviour patterns that they also need people who will take programmed decisions efficiently and thus ensure effective and efficient day-to-day work? This may only be realised by an attempt to develop roles P and A in those managers who are responsible for education and training in organisation - at least to an extent that they will be able to understand, to appreciate and to involve actively people with roles $\mathrm{P}$ and $\mathrm{A}$ in their behaviour patterns.

Considering our findings that programmed decisions are more efficient in more complex organisational systems, we can establish that abilities of those people who are able to take mainly non-programmed decisions may be doomed to failure unless such organisations are managed by people who master programmed way of decision making to an excellent level.

\section{References}

Adizes, I. (1981). How to Solve the Mismanagement Crisis, Adizes Institute, Santa Monica

Adizes, I.: http://www.adizes.com 
Knowledge and Decision Making

Belbin, M. (1993). Team Roles at Work, Butterworth-Heinemann Ltd, London

Belbin, M.: www.belbin.com

Bernik, J. (1998) Vpliv vedenja vodij na uspešnost podjetja - magistrsko delo, Ekonomska fakulteta, Ljubljana

Colbe, K.: http://www.colbe.com

Gostiša, M. (1996) Participativni management - sodobna teorija in praksa organizacijske udeležbe zaposlenih v svetu in pri nas. ČZP Enotnost in Studio Participatis, Ljubljana

Lipičnik, B. (1998) Ravnanje z ljudmi pri delu, Gospodarski vestnik, Ljubljana

Lipičnik, B. (1999) Vedenjski vzorci dveh generacij študentov, Zbornik posvetovanja - Evropska skupnost in management, FOV, Portorož, 1. knjiga, str. $226-232$.

Lipičnik, B., Gonan-Božac, M. (2000) Mednarodna primerjava vedenjskih vzorcev študentov, Zbornik posvetovanja z mednarodno udeležbo, Zbornik posvetovanja - Management v novem tisočletju, FOV, Portorož, str. 248 - 256

\section{Biography}

Bogdan LIPICNIK, Associate Professor at the Faculty of Economics, University of Ljubljana, Republic Slovenia. He was born 26th September, 1946. Subject of his research and lecturing: Organizational Behaviour and Theory, Human Resources Management, Motivation, Leadership and Group Behaviour in Organizations, Psychological Climate, Organizational Culture, etc. Details of education: B.A. in Industrial Psychology at University of Ljubljana (1971), M.A. in Organization and Economics at Faculty of Economics University of Ljubljana (1983), Ph.d. in Organization at University of Maribor (1987). 